\title{
Neonatal Herpes Simplex Infection
}

National Cancer Institute

\section{Source}

National Cancer Institute. Neonatal Herpes Simplex Infection. NCI Thesaurus. Code C115988.

Infection in the first month of life caused by the Herpes simplex virus. 